\title{
MIĘDZY WOLNOŚCIĄ A BEZPIECZEŃSTWEM - SPOLECZNE I PRAWNE SKUTKI ZAMACHÓW TERRORYSTYCZNYCH W EUROPIE POCZĄTKU XXI WIEKU
}

\begin{abstract}
ABSTRAKT: Światem początku XXI w. wstrząsnęły dramatyczne i jakże tragiczne w skutkach zamachy terrorystyczne. 11 września 2001 r. runęły wieże WTC w Nowym Jorku. Trzy lata później bomby wybuchły w Madrycie, a następnie w Londynie. Lata 2015-2016 to cała seria zamachów w Europie. Każdy kolejny incydent niósł za sobą zmianę w poczuciu zagrożenia terroryzmem we wszystkich państwach europejskich. Zauważalna stała się radykalizacja poglądów i postaw ludzkich co do sposobów walki z terroryzmem. Przełożyło się to także na postrzeganie innych, obcych nacji $\mathrm{w}$ poszczególnych państwach. Podejmując walkę $\mathrm{z}$ terroryzmem poszczególne państwa po kolei wprowadzały zmiany prawa, z jednej strony dające nowe, duże możliwości działania służbom odpowiedzialnym za bezpieczeństwo, $\mathrm{z}$ drugiej zaś w dużym stopniu ograniczające prawa i wolności obywatelskie.
\end{abstract}

SŁOWA KLUCzowe: terroryzm, walka z terroryzmem, prawa człowieka, wolności obywatelskie, swobody obywatelskie, prawo antyterrorystyczne

\section{BETWEEN FREEDOM AND SECURITY - THE SOCIAL AND LEGAL CONSEQUENCES OF TERRORIST ATTACKS IN EUROPE IN THE EARLY 21ST CENTURY}

\begin{abstract}
The world of the beginning of the 21st century was shocked by dramatic and very tragic terrorist attacks. On September 11, 2001, the WTC towers in New York collapsed. Three years later, bombs exploded in Madrid and then in London. Years 2015-2016 were marked by a series of attacks in Europe. Each subsequent incident brought a change in the sense of threat to terrorism in the communities of all European countries. The radicalization of human views and attitudes regarding ways to combat terrorism has become noticeable. This also translated into the perception of others - foreign nations in each country. Taking the fight against terrorism, individual countries introduced law changes. On the one hand it's giving new and powerful opportunities for security services, on the other hand, significantly limiting civil rights and freedoms.
\end{abstract}

KEYWORDS: terrorism, fight against terrorism, human rights, civil liberties, civil liberties, anti-terrorism law

\footnotetext{
${ }^{1}$ University of Warsaw; Poland.
} 


\section{WPROWADZENIE}

Prawo do wolności to niewątpliwie podstawa demokracji. Wolność człowieka, wolność słowa, wolność przemieszczania się, wyznania, gromadzenia, wolność gospodarcza, wolność prasy - wymieniać można byłoby jeszcze bardzo długo. Obywatele współczesnych, demokratycznych państw przyzwyczaili się żyć w duchu dobrodziejstwa, jaką jest właśnie ta wartość. Została ona wpisana w konstytucje poszczególnych państw, a to z kolei skutkowało ustawodawstwem będącym realizacją prawa do wolności. Ograniczenie tegoż prawa może nastąpić wyłącznie w ustawowo uregulowanych sytuacjach. Jak pokazuje historia, ograniczenia tejże wolności były zazwyczaj podyktowane chęcią zapewnienia spokojnego życia, opartego o wartości i prawo przyjęte w danej społeczności. Chęć minimalizacji zagrożeń wynikających z bezprawnych działań ludzkich, prowadziła $z$ czasem do zmian prawnych ograniczających wolność jednych na rzecz realizacji prawa do wolności i bezpieczeństwa drugich. W ten oto sposób wolność stawała się nierozerwalnie związana $\mathrm{z}$ realizacją potrzeby bezpieczeństwa. Tą ostatnią $\mathrm{w}$ niespotykanej dotychczas skali iw niespotykany sposób zachwiały wydarzenia początku XXI w., a były nimi zamachy terrorystyczne w Stanach Zjednoczonych i w Europie. Zmieniły one postrzeganie zarówno wolności, jak i bezpieczeństwa i doprowadziły do potrzeby wprowadzenia zmian prawnych, które pozwalały na daleko idącą ingerencję w sferę swobód obywatelskich i prywatności. Chcąc przyjrzeć się źródłom przesuwania granic pomiędzy prawem do wolności a bezpieczeństwem a niewątpliwie jednym $\mathrm{z}$ nich stało się $\mathrm{w}$ ostatnich latach zagrożenie terrorystyczne przeanalizowano przebieg poszczególnych zamachów i skutki społeczne, polityczne, a także prawne, które temu towarzyszyły, i to stanowiło przedmiot podjętych badań. Ich celem zaś było przedstawienie rzeczywistego przebiegu procesu zmian postrzegania kwestii bezpieczeństwa ogólnego i wolności obywateli Europy. Było to nierozerwalnie związane $\mathrm{z}$ rosnącym zagrożeniem, potęgowanym przez kolejne zamachy terrorystyczne i przełożyło się na chęć wprowadzenia zmian prawnych bardziej lub mniej radykalnych w swoim wymiarze. Pomocne i uzasadnione metodologicznie było w tym przypadku chronologiczne opisanie kolejnych aktów terroru i skutków, jakie one wywoływały. Głównym problemem badawczym postawionym przez autora było znalezienie odpowiedzi na pytanie: w jaki sposób w tak krótkim czasie doszło do tak daleko idących zmian postaw społecznych, aw ich następstwie także zmian prawnych, skutkujących wyrażeniem zgody na rezygnację z części praw i swobód obywatelskich na rzecz realizacji brawa do bezpieczeństwa?

Chcąc przeprowadzić dogłębnie opisywane badanie naukowe zdecydowano się na wykorzystanie kilku metod badawczych, pozwalających na jak najszersze spojrzenie na podjęty problem badawczy i jego jak najgłębszą analizę. Zastosowano w tym celu metodę monograficzną pozwalającą głęboko wniknąć w istotę zjawiska poprzez wszechstronne ukazanie badanego procesu zmian społecznych i prawnych za pomocą przedstawionych faktów i danych. Metodę tę uzupełniono badaniem dokumentów i oceną indywidualnych przypadków, całość zaś poddano analizie i krytyce wykorzystanych źródeł. Źródłami tymi 
były przede wszystkim relacje medialne (artykuły, materiały radiowe i telewizyjne, depesze agencyjne) opisujące kolejne zamachy, a także reakcje społeczeństw poszczególnych państw na nie, wyniki badań opinii społecznej, wypowiedzi ekspertów i polityków poszczególnych państw, projekty zmian prawa i wdrażane w życie akty prawne oraz opinie organizacji pozarządowych. To wszystko skonfrontowano z dotychczasowymi poglądami naukowymi wyrażonymi w dostępnej literaturze badań nad terroryzmem.

\section{WPLYW ZAMACHÓW TERRORYSTYCZNYCH NA RADYKALIZACJE POSTAW SPOEECZNYCH W EUROPIE}

Po 11 września 2001 r. i zamachach na World Trade Center mówiło się głośno, że życie nigdy już nie będzie takie samo. Ten głos był jeszcze bardziej donośny po kolejnych, tym razem europejskich zamach w Madrycie (2004 r.) i Londynie (2005 r.). Służby poszczególnych państw rozpoczęły zakrojone na szeroką skalę działania, które $\mathrm{z}$ jednej strony nastawione były na ustalenie sprawców zamachów, $\mathrm{z}$ drugiej zaś na niedopuszczenie w przyszłości do takich wydarzeń. Były one na tyle skuteczne, że przez kolejne siedem lat można było odnieść wrażenie, że problem zmarginalizowano. Wierzono, bądź chciano wierzyć w to, że współdziałające ze sobą służby poszczególnych państw, opierając się o istniejące wówczas regulacje prawne i dysponując odpowiednio zaawansowaną technologią potrafią zapewnić poszczególnym krajom bezpieczeństwo. W odbiorze społecznym funkcjonowało przekonanie, że ryzyko zamachu może $\mathrm{i}$ istnieje, ale jest ono znacznie mniejsze, aniżeli było wcześniej. Jeżeli już gdzieś do zamachu dochodziło, bądź mogło dojść, to raczej nie w Europie i nie w Stanach Zjednoczonych, które uważano za bezpieczne. Przynajmniej tak sądzili zwykli obywatele, dla których informacje wywiadowcze nie były i nie są dostępne.

Tę wiarę w bezpieczeństwo - szanującej drugiego człowieka i otwartej na inne kultury Europy - 9 marca 2012 r. zachwiał Mohamed Merah. Ten 23-letni Francuz pochodzenia algierskiego, radyklany islamista zabił w Tuluzie i pobliskim Montauban najpierw trzech żołnierzy, a następnie przed żydowską szkołą zastrzelił trójkę dzieci i jedną osobę dorosłą. Wtedy jeszcze potraktowano ten zamach jedynie jako tragiczny incydent. Oto niezadowolony, rozgoryczony, narcystyczny psychopata - jak go określili psychologowie - natchniony ideologią nienawiści wobec chrześcijańskiego i judaistycznego świata, działając w pojedynkę postanowił uderzyć w to, czego nie akceptował. Taka narracja na temat podłoża zamachu mogła uspakajać racjonalnie myślącego człowieka. Jak się później okazało, takich pojedynczych żołnierzy, gotowych nawet na samobójczy atak, w niedalekiej przyszłości było znacznie więcej. Ze wzmożoną siłą objawili się oni na początku stycznia 2015 r. w Paryżu, zabijając 17 osób.

7 stycznia 2015 r. bracia Said i Cherif Kouachi w redakcji „Charlie Hebdo” zastrzelili 12 osób. Powiązany z tymi terrorystami Amedy Coulibaly dzień później zabił w stolicy Francji policjantkę, a w kolejnym dniu w sklepie z koszerną żywnością zastrzelił cztery inne osoby. Dla wielu było już wówczas pewne, że Francję, kraj „wolności, równości i braterstwa” 
z jednej strony, z drugiej zaś kraj mieszkających w gettach, niezasymilowanych francuskich potomków tych, którzy przyjechali z byłych kolonii, czeka ciężki czas².

Minęło 11 miesięcy i nastąpił kolejny atak. Tym razem w Paryżu. Zamach ten, jak się okazało, był preludium kolejnych tego typu wydarzeń. Na rządzących Francją, a potem także innych państw europejskich wymusiły one podjęcie zdecydowanych działań prawnych, dających nadzieję na większą skuteczność służb bezpieczeństwa w zapobieganiu i zwalczaniu terroryzmu. Oczywiście odbyło się to przy jednoczesnym ograniczeniu wolności obywatelskich.

13 listopada 2015 r. na przedmieściach Paryża, przed stadionem narodowym Stade de France, na którym trwał mecz reprezentacji Francji i Niemiec, pojawili się trzej mężczyźni: Bial Hadfi, Ahmad Al-Mohammed i Ahmad Almohammad. Wydawało im się, że przygotowany przez nich plan był prosty. Należało najpierw dostać się na trybuny, a następnie, będąc już wśród kibiców, zdetonować ładunki wybuchowe, które mieli na sobie. Zabijając siebie, mieli zabić jak najwięcej niewiernych.

To, co na etapie planowania wydawało się łatwe, znacznie trudniejsze okazało się w rzeczywistości. Pierwszym problemem nie do pokonania dla trójki mężczyzn stała się ochrona obiektu. Ta zadziałała zgodnie z procedurami i zamachowców nie dysponujących biletami wstępu na mecz po prostu nie wpuszczono na teren stadionu. Ta porażka nie oznaczała jednak zaprzestania zaplanowanej akcji. Plan trzeba było szybko zmodyfikować i działać dalej. Zamach na stadionie miał zainicjować kolejne tego typu akcje. Dżihad, czyli święta wojna z niewiernymi nie mogła zakończyć się $\mathrm{w}$ tym momencie. Zdesperowani i prawdopodobnie mocno poddenerwowani sprawcy nie zastanawiając się zbyt długo zdecydowali się na atak w miejscach, w których akurat się znajdowali. Dwóch zamachowców znajdowało się w okolicach bramek bezpieczeństwa, trzeci zaś w oddalonej kilkaset metrów restauracji. Cudem tylko można określić fakt, że w wyniku tego ataku zginęła zaledwie jedna osoba i nikt nie został ranny ${ }^{3}$. Po pierwszych eksplozjach słyszalnych nie tylko na boisku piłkarskim (reakcje piłkarzy i kibiców ze stadionu Stade de France wielokrotnie pokazywały telewizje całego świata) informacje o nieznanym jeszcze incydencie bombowym szybko obiegły media.

Jednocześnie w Paryżu rozpoczęły się ataki kolejnych dwóch grup terrorystów. Kilka minut po zamachu przy stadionie inna grupa zamachowców otworzyła ogień do klientów siedzących przy stolikach przed paryskimi kawiarniami w centrum miasta. Do ludzi strzelano z jadącego samochodu. W jego kabinie siedziało trzech mężczyzn, jak się później okazało w wyniku policyjnego dochodzenia - trzech braci. Jadąc kolejno ulicami Paryża przed lokalami Le Petit Cambodge, Caffe Bonne Pierre, Le Carillon, La Belle Equipe i La Casa Nostra zastrzelili 39 osób. $\mathrm{Z}$ trójki braci odpowiedzialnych za ten atak przeżył jeden - Salah Abdeslam. To on kierował autem, z którego strzelano. Samochód porzucił w okolicach Bulevard Voltaire detonując je wraz

\footnotetext{
${ }^{2}$ Raport agencji AFP: Attaque de Charlie Hebdo, AFP, 07.01.2015, https://www.afp.com/fr/attaque-de-charliehebdo, (08.01.2019).

3 Attaques à Paris: le point sur l'enquête et le déroulé des attaques, Le Monde.fr, 15.11.2015, http://www.lemonde.fr/societe/article/2015/11/13/fusillade-meurtriere-a-

paris_4809485_3224.html\#ZYBoBIuh7diAApS7.99, (18.11.2018).
} 
$\mathrm{z}$ siedzącym $\mathrm{w}$ środku swoim młodszym bratem Ibrahimem. Trzeci z braci poniósł śmierć detonując swój pas szahida ${ }^{4}$.

Kolejna, także trzyosobowa, uzbrojona w karabiny grupa wdarła się do sali koncertowej Le Bataclan, gdzie trwał koncert kalifornijskiej grupy Eagles of Death Metal. Trzej napastnicy - Omar Ismail Mostefai, Samy Amimour i Foued Mohamed-Aggad, na oślep strzelali do zgromadzonych w środku ludzi zabijając 89 osób. W trakcie szturmu francuskich antyterrorystów zginęli także zamachowcy. Dwóch wysadziło się detonując ładunki wybuchowe, które mieli na sobie, trzeciego zaś policjanci zastrzelili w trakcie akcji. Prawdopodobnie nie udało mu się skutecznie uruchomić ładunku zawieszonego na pasie ${ }^{5}$. Łącznie w zamachu 13 listopada 2015 r. zginęło 130 osób pochodzących z 26 krajów.

Tuż po tych tragicznych wydarzeniach prezydent Francji, Francois Hollande, thumaczył (niejako usprawiedliwiając brak wiedzy służb o planowanych zamachach), że w jego kraju w ostatnim r. udaremniono skutecznie kilka ataków terrorystycznych. Słowo „udaremniono” świadczyć miało o dotychczasowym prawidłowym i skutecznym działaniu służb. Holland postawił jednak wyraźną granicę pomiędzy stanem pokoju, zakłócanym przez niebezpieczne w skutkach „incydenty”, w którym do tej pory była Francja, a „stanem wojny”, w który ten kraj przeszedł ${ }^{6}$. Wojny tej Francja z pewnością nie chciała. A skoro już do niej doszło, to z pewnością nie chciała prowadzić jej sama. Po pierwsze dlatego, że walka w pojedynkę z góry skazana byłaby na porażkę, a po drugie, zagrożenie ze strony ekstremistów islamskich dotyczyło całej Europy.

Po zamachu paryskim w całej Europie wzmocniono środki bezpieczeństwa. We Francji w stan najwyższej gotowości postawiono policję, żandarmerię i służby specjalne wspierane przez wojsko. Prezydent Francji, Francois Holland, wprowadził na trzy miesiące stan wyjątkowy i przywrócił kontrole na granicach, podkreślając jednocześnie, że za zwiększeniem środków bezpieczeństwa musi pójść także zwiększenie wydatków budżetowych na nie. „Bezpieczeństwo jest ważniejsze niż zasady budżetowe" - stwierdził Holland przedstawiając jednocześnie plany stworzenia $\mathrm{w}$ ciągu następnych dwóch lat we francuskiej policji 5 tysięcy miejsc pracy i wstrzymanie jakichkolwiek redukcji w armii do 2019 r. W miarę upływu kolejnych dni rząd francuski zadeklarował wzrost nakładów budżetowych na obronę kraju o kolejne 4 miliardy euro i zwiększenie stanu liczbowego armii. Armia francuska miała zwiększyć swoją liczbę z 66 do 77 tysięcy żołnierzy i z 28 do 40 tysięcy rezerwistów. W rzeczywistości jednak na ulice Paryża do służby skierowano dodatkowo 1500 żołnierzy, a zapowiedzianą walkę kontynuowano tymi

\footnotetext{
${ }^{4}$ A.J. Rubin, Paris: One year on, „The New York Times”, 12.11.2016, http://www.nytimes.com/2016/11/ 13/world/europe/paris-one-year-on.html, patrz także: 'I saw a hole in her face, and realised she'd been shot': Gunman dressed in black picked off terrified diners firing 'professional bursts' of shots in cafe shooting rampage, „Daily Mail”, 14.11.2015, http://www.dailymail.co.uk/ news/article-3318086/11-dead-terrorists-openfire-Paris-restaurant.htm, (20.11.2018).

${ }^{5}$ Joyous crowd wave and smile as they enjoy Eagles Of Death Metal concert... before 89 of them were murdered by ISIS gunmen, „Daily Mail”, 17.11.2015, http://www.dailymail.co.uk/news/article-3320420/Joyous-crowd-wave-smileenjoy-Eagles-Death-Metal-concert-just-moments-89-murdered-ISIS-gunmen.html, (15.11.2018).

6 Le Monde,13.11.2015, http://www.lemonde.fr/attaques-a-paris/video/2015/11/16/hollande-maintient-saposition-la-france-est-en-guerre_4811152_4809495.html, (15.11.2018).
} 
siłami, które pozostawały do tej pory w dyspozycji państwa francuskiego. Zaczęła się zakrojona na szeroką skalę operacja antyterrorystyczna prowadzona w kraju i poza jego granicami ${ }^{7}$.

W ramach odwetu siły lotnicze Francji rozpoczęły bombardowanie terenów Państwa Islamskiego, które przyznało się do zamachów. W rejon Zatoki Perskiej skierowano lotniskowiec Charles de Gaulle, który miał wesprzeć działania przeciwko terrorystom. To Syria zdaniem prezydenta Francji stała się w ostatnim czasie największą na świecie „fabryką produkującą terrorystów" $"$

Według danych przedstawionych przez francuski rząd w ciągu jednego zaledwie miesiąca (do połowy grudnia 2015 r.) służby odpowiedzialne za bezpieczeństwo wewnętrzne Francji przeprowadziły ponad 2700 obław. W ich efekcie 51 osób zostało aresztowanych, wobec 360 zaś zarządzono areszt domowy ${ }^{9}$. W zdecydowanej większości zarzuty dotyczyły nielegalnego posiadania broni i obrotu narkotykami. Oczywiście istotne było również to, że zatrzymywane osoby podejrzewano o aktywne związki z organizacjami terrorystycznymi.

Oceniając stan zagrożenia terrorystycznego brytyjski premier, David Cameron, oświadczył: „Paryski atak zmienił spojrzenie Brytyjczyków na terror. Musimy być przygotowani na gorsze”10. Wypełnieniem jego słów była zapowiedź dodatkowej rekrutacji 2000 agentów skierowanych do rozpoznania środowisk ekstremistycznych, wewnątrz których mogą rekrutować się terroryści. Mieli być oni wsparciem dla obciążonych dużą liczbą zadań agentów wywiadu MI5, MI6 i GCHQ organizacji wywiadowczej powołanej do ochrony bezpieczeństwa narodowego, której głównym zadaniem jest identyfikacja i analiza zagrożeń terrorystycznych w wymiarze międzynarodowym ${ }^{11}$.

Dzień po zamachu niemiecka policja poinformowała o zatrzymaniu w okolicach Monachium mieszkańca Czarnogóry, w którego samochodzie znaleziono ładunki wybuchowe oraz broń. Jak donosił „Die Welt”, powołując się na śledczych, on także mógł być wspólnikiem zamachowców z Francji ${ }^{12}$. O udaremnieniu zamachu, planowanego prawdopodobnie w tym samym czasie, co w Paryżu, mówiły też służby tureckie. W połowie listopada 2015 r. także włoscy karabinierzy przedstawili opinii publicznej efekty, jak podkreślano wielokrotnie, największej od 20 lat operacji policyjnej wymierzonej w siatkę terrorystyczną. We Włoszech,

\footnotetext{
${ }^{7}$ C. Ducourtieux, P. Roger, Déficits, Bruxelles comprend la „priorité” donnée par la France „à la sécurité”, „Le Monde”, 17.11.2015, http://www.lemonde.fr/attaques-a-paris/article/2015/11/17/francois-hollande-sedelivre-du-pacte-de-stabilite_4811769_4809495.html, Vide: H. Orzechowski, Francja krwawi, ale się nie poddaje, „Newsweek”, 13.11.2016, http://www.newsweek.pl/swiat/rok-po-zamachach-w-paryzu-jak-francjawalczy-z-isis, artykuly,400450,1.html, (20.11.2018).

${ }^{8}$ P. Henn, Francois Hollande declares France is now at WAR with ISIS with second night of bombings, „Express”, 17.11.2015, http://www.express.co.uk/news/world/619784/ Hollande-France-war-ISIS-Paris-attacks, (21.11.2018).

9 Paris attacks: French police arrest suspect, BBC, 15.12.2015, http://www.bbc.co.uk/news/world-europe35102595, (12.11.2018).

${ }^{10}$ David Cameron warns there may be British casualties in the Paris terror attack and tells France: ,We will do whatever we can to help”, „Daily Mail”, 14.11.2015, http://www.dailymail.co.uk/news/article-3318273/Wehelp-David-Cameron-chair-emergency-Cobra-meeting-Paris-attacks-British-nationals-France-warned-stayindoors.html\#ixzz4QMaWf8x8, (18.11.2020).

11 „Daily Mirror”, 16.11.2015, s. 4-5;

12 Das sind die offenen Fragen nach dem Terror von Paris, „Die Welt”, 16.11.2015, https://www.welt.de/ politik/ausland/article148867136/Das-sind-die-offenen-Fragen-nach-dem-Terror-von-Paris.html, (14.01.2019).
} 
Szwecji, Norwegii, Wielkiej Brytanii i Szwajcarii zatrzymano łącznie 17 osób, które miały planować zamachy na parlamentarzystów i dyplomatów ${ }^{13}$. Ponadto zaraz po zamachu w Paryżu włoskie władze zapowiedziały wzmocnienie działań na rzecz bezpieczeństwa przez policję i wojsko. Na ulice Wiecznego Miasta trafiło w pierwszym rzucie 1500 żołnierzy. W kolejnych dniach, w trybie pilnym uzupełniono tę liczbę o dodatkowych 700 przedstawicieli armii włoskiej ${ }^{14}$.

Jeżeli do tych wszystkich zdarzeń, z zaledwie kilku listopadowych dni 2015 r., dodamy jeszcze zamach w Bejrucie, w którym zginęło co najmniej 41 osób, a kilkaset zostało rannych ${ }^{15}$ czy katastrofę rosyjskiego samolotu pasażerskiego z 224 osobami na pokładzie, do której spowodowania również przyznali się dżihadyści ${ }^{16}$, to obraz światowego bezpieczeństwa nie malował się w jasnych barwach.

Francja zdawała sobie zapewne sprawę $\mathrm{z}$ tego, że atrakcyjnym celem organizacji terrorystycznych będą mistrzostwa świata w piłce nożnej Euro 2016. W stan najwyższej gotowości postawiono wówczas służby, wzmożono wymianę informacji na temat zagrożeń $\mathrm{z}$ innymi państwami tak, by nie dopuścić do ewentualnego spektakularnego ataku. Wreszcie postanowiono kontrolować i uniemożliwiać - na ile tylko to możliwe - komunikację prowadzoną za pośrednictwem Internetu pomiędzy członkami ugrupowań terrorystycznych. Miał w tym pomóc dekret nr 2015-125 z 5 lutego 2015 r. ${ }^{17}$ podpisany przez prezydenta i premiera Francji ułatwiający blokowanie stron związanych z terroryzmem i pedofilią.

Wyzwaniem $w$ walce $\mathrm{z}$ terroryzmem stały się także inspirowane $\mathrm{i}$ organizowane za pośrednictwem Internetu wyjazdy obywateli starego kontynentu do Syrii i Iraku, w celu zasilenia szeregów dżihadystów. Międzynarodowe Centrum Studiów nad Radykalizacją w raporcie ze stycznia 2015 r. szacowało liczbę takich osób na 4 tysiące - najwięcej z Francji, choć spora reprezentacja pochodziła także z Belgii, Danii i Holandii. Dla porównania w maju 2015 r. francuskie ministerstwo spraw wewnętrznych szacowało, że w walkę po stronie dżihadystów zaangażowanych było 1683 obywateli Francji, co oznaczało 203 procentowy wzrost w stosunku do początku 2014 r. ${ }^{18} \mathrm{~W}$ Belgii, która wśród wszystkich europejskich

\footnotetext{
${ }^{13}$ European swoop seizes 15 Islamists police say planning attacks, „Reuters”, 12.11.2015, http://uk.reuters.com/ article/uk-italy-arrests-idUKKCNOT10NZ20151112, (12.11.2018).

14 Rinaldo, Frignani, Giubileo, arrivano i rinforzi Entro breve altri 1.500 militari, roma.coriere.it, http://roma.corriere.it/notizie/cronaca/15_dicembre_21/giubileo-arrivano-rinforzi-entro-breve-altri-1500militari-09994f46-a7fc-11e5-927a-42330030613b.shtml?refresh_ce-cp, (18.01.2019).

${ }^{15}$ Liban: Podwójny atak bombowy. Co najmniej 41 zabitych i 200 rannych. Depesza Polskiej Agencji Prasowej, PAP, 12.11.2015.

${ }^{16}$ Katastrofa rosyjskiego samolotu, TVN24, http://www.tvn24.pl/raporty/katastrofa-rosyjskiego-samolotu,1021, (23.01.2019).

${ }^{17}$ Dekret nr 2015-125 z dnia 05 lutego 2015 odnoszący się do blokowania witryn skutkujących aktami terroryzmu lub które propagują pornografię nieletnich, legifrance.gouv.fr, https://www.legifrance.gouv.fr/ affichTexte.do?cidTexte=JORFTEXT000030195477, (20.01.2019).

${ }_{18}$ M. Wróblewska-Łysik, Zaangażowanie Francji $w$ walkę z terroryzmem po zamachu na "Charlie”, „Bezpieczeństwo Narodowe” nr 3, 2015 r., s.69, za: P. Neumann, Foreign fighter total in Syria/Iraq now exceeds 20,000; surpasses Afghanistan conflict in the 1980s, 26 stycznia 2015 r., http://icsr.info/2015/01/foreign -fighter-total-syriairaq-now-ex-ceeds-20000-surpasses-afghanistan-conflict-1980s/, (18.11.2018); Vide: Le Parisien, 15 maja 2015 r., http://www. leparisien.fr/faits-divers/jihadisme-cazeneuve-detaille-l-origine-desfrancais-impliques -19-05-2015 -4783609.php, (18.11.2018).
} 
nacji, w przeliczeniu na liczbę mieszkańców miała najwyższy wskaźnik zaangażowania obywateli po stronie dżihadystów w Syrii, liczba ta była w 2015 r. szacowana na poziomie od 350 do 550 osób $^{19}$. W samej tylko Austrii jeszcze w 2014 r. władze podejrzewały około 130 swoich obywateli o ścisłe powiązania $\mathrm{z}$ zagranicznymi ugrupowaniami walczących islamistów. Już wtedy austriackie MSW alarmowało, że liczba takich osób w ostatnich latach znacznie wzrosła. Konrad Kogler - dyrektor ds. bezpieczeństwa publicznego Austrii, w jednej ze swoich wypowiedzi stwierdził, że grupa ta dzieliła się na „ludzi czynnie uczestniczących w walce lub takich, które powróciły już do Austrii”. Zaznaczył przy tym, że obie te grupy są przedmiotem zainteresowania służb ${ }^{20}$.

Euro 2016 przebiegło spokojnie. Emocje opadły. Upływ czasu spowodował, że opadła również czujność w zakresie działań antyterrorystycznych. O ich skuteczności zapewniał wówczas premier Manuel Valls mówiąc przed Zgromadzeniem Narodowym, że w ciągu 4 lat udaremniono 16 ataków ${ }^{21}$. Wszystko to zbiegło się w czasie z sezonem urlopowym, który dotyczył także sporej grupy funkcjonariuszy. Po mistrzostwach Europy w piłce nożnej w 2016 r. pracownikom służb odpowiedzialnym za bezpieczeństwo trzeba było oddać dni wolne. Wtedy nastąpił kolejny atak.

14 lipca 2016 r. świat stał się świadkiem szaleńczego ataku w Nicei, dokonanego przez Mohameda Lahouaiej Bouhlela - 31-letniego Tunezyjczyka mieszkającego we Francji. W trakcie obchodów święta upamiętniającego zburzenie Bastylii rozpędzoną ciężarówką wjechał w thum ludzi zgromadzonych na promenadzie. Zabił 84 osoby, a 202 ranił. Zamachowca w trakcie zatrzymywania zastrzelili policjanci. Machina działania służb odpowiedzialnych za bezpieczeństwo znów ruszyła, choć wydawać by się mogło, że powinna była ona działać nieprzerwanie na najwyższym poziomie. Przecież cały czas we Francji - do 25 lipca 2016 r. - trwał stan wyjątkowy.

Rozpoczęto poszukiwania ewentualnych współorganizatorów zamachu. Publicznie zadawano pytania: dlaczego do niego doszło i czy służby stanęły na wysokości zadania? Pod adresem władz państwa padły oskarżenia. Na łamach dziennika „Liberation” ministrowi spraw wewnętrznych Francji - Bernardowi Cazeneuve, zarzucono niewłaściwe przygotowanie zabezpieczenia imprezy, niedostateczną (znacznie niższą od oficjalnie deklarowanej) liczbę policjantów ochraniających obchody i w końcu naciski na lokalną policję, by ta zmieniła raport dotyczący liczby funkcjonariuszy pełniących służbę tego krytycznego dnia ${ }^{22}$.

Po zamachu w Nicei francuskie władze ogłosiły trzydniową żałobę narodową. O kolejne trzy miesiące przedłużono stan wyjątkowy. Prezydent Francois Holland oznajmił, że walka z terroryzmem ,potrwa długo”. Zapowiedział wzmocnienie działań militarnych

\footnotetext{
${ }^{19} \mathrm{~W}$ liczącej 11 mln mieszkańców Belgii liczba Muzułmanów szacowana jest na ok. 0,5 mln, za: Jason Burke, How Belgium became a breeding ground for international terrorists, „The Guardian”, 16.11.2015.

20 Austria: Rośnie liczba osób powiązanych z walczacymi islamistami, 22.08.2014, http://wpolityce.pl/ swiat/210482-austria-rosnie-liczba-osob-powiazanych-z-walczacymi-islamistami, (23.01.2019).

21 W. Adamska, Zwalczanie terroryzmu we Francji: między faktami a mitami https://panoptykon.org/ wiadomosc/ zwalczanie-terroryzmu-we-francji-miedzy-faktami-mitami, (18.11.2018).

${ }^{22}$ S. Mouillard, W. Le Devin, I. Halissat, Attentat de Nice: la réponse de «Libération» à Bernard Cazeneuve, 21.07.2016, http://www.liberation.fr/france/2016/07/21/attentat-de-nice-la-reponse-de-liberation-a-bernard-caz eneuve_1467612, (20.11.2018).
} 
w walce z terroryzmem w Syrii i Iraku tak, by uderzyć „w tych, którzy atakują nas na naszym terytorium"23. Nie była to z pewnością prosta walka, a same bombardowania terenu Syrii określanej mianem największej na świecie „fabryki produkcji terrorystów” - z pewnością nie wystarczały. Wydawało się jednak, że jak nigdy dotąd skrystalizowała się silna potrzeba wzmocnienia zarówno działań wywiadowczych służb odpowiedzialnych za walkę z terroryzmem w poszczególnych krajach, jak i działań prewencyjnych realizowanych przez policję i być może także wojsko. Ważne jednak, by wszystko to odbywało się przy realnym nie zaś deklaratywnym wzmocnieniu zabezpieczenia granic zewnętrznych Unii Europejskiej. W przeciwnym razie wrastało ryzyko upadku dziedzictwa układu z Schengen.

Atak w Nicei potępili światowi przywódcy. Papież Franciszek - głowa kościoła katolickiego, określił to, co się stało, mianem „zbrodniczego szaleństwa”24. Niektóre państwa, jak chociażby Hiszpania, Włochy i Niemcy, wzmocniły środki bezpieczeństwa w rejonie przygranicznym.

Wzrost poczucia zagrożenia, jak to zawsze bywało w takich sytuacjach, szybko przełożył się na dosyć powszechną aprobatę dla zwiększenia uprawnień służb kosztem swobód obywatelskich. Ten fakt potwierdził sondaż przeprowadzony przez IFOP po zamachach w Nicei, z którego wynikało, że aż 81\% Francuzów było skłonnych wyrazić zgodę na więcej kontroli i ograniczenia wolności. 68\% opowiedziało się za izolowaniem „na wszelki wypadek” osób zarejestrowanych jako zagrażające bezpieczeństwu państwa. Zaledwie 3\% badanych uznało, że uprawnienia służb są zbyt duże $\mathrm{e}^{25}$.

Bezpośrednio po zamachach paryskich w listopadzie 2015 r. bardzo uaktywniły się także służby bezpieczeństwa Belgii, zapowiadając rozpoczęcie działań antyterrorystycznych na dużą skalę. Można by rzec: dobrze, że to nastąpiło. Jednakże rodzi się pytanie: dlaczego tak późno i dlaczego dopiero po tak tragicznym zamachu? Z pewnością jednak swoją rolę w walce $z$ terroryzmem ten kraj musiał odegrać. Tym bardziej, że krytyka dotychczasowej postawy władz belgijskich co do przymykania oczu na sprawy związane z rozrastającym się ekstremizmem islamskim popłynęła bardzo szeroką falą. Media brytyjskie, a za nimi także te w pozostałej części Europy określiły Belgię mianem „wylęgarni ekstremizmu”26.

Warto w tym miejscu cofnąć się do 2001 r. i przypomnieć, że dwa dni po zamachu na World Trade Center (13 września 2001 r.) w Uccle na przedmieściach Brukseli zatrzymano 31-letniego Nizara Trabelsi - piłkarza tunezyjskiego pochodzenia, którego podejrzewano o zaplanowanie i przygotowanie ataku na ambasadę USA w Paryżu, a następnie skazano za

\footnotetext{
${ }^{23}$ Wystąpienie telewizyjne prezydenta Francois Holland'a z 15.07.2016 rok, http://www.rfi.fr/france/20160715attaque-nice-francois-hollande-parle-acte-terroriste, (25.01.2019).

24 Servizio Informazione Religiosa, http://agensir.it/quotidiano/2016/7/15/papa-francesco-condanna-per-folliaomicida-a-nizza/, (25.01.2019).

25 W. Adamska, Zwalczanie terroryzmu we Francji: między faktami a mitami, https://panoptykon.org/ wiadomosc/zwalczanie-terroryzmu-we-francji-miedzy-faktami-mitami, (25.01.2019).

26 ,Daily Mirror”, 16.11.2015.
} 
ten czyn na karę 10 lat więzienia ${ }^{27}$. W 2003 r. także w Belgii zatrzymano pochodzącego z Tunezji Belga, zarzucając mu udział w siatce terrorystycznej, która pomogła dostarczyć fałszywe dokumenty zabójcom Ahmada Szaha Masuda - afgańskiego dowódcy Sojuszu Północnego, broniącego wolne terytoria Afganistanu przed talibami. Udany zamach na niego miał miejsce 7 listopada $2001 \mathrm{r}^{28}$

Początek ubiegłej dekady to zauważalne już wtedy zaangażowanie obywateli Belgii w działania po stronie Al-Kaidy w Iraku. W kolejnych latach dziesiątki młodych ludzi wyjeżdżały na Bliski Wschód by wspomagać terrorystów. Wśród nich była także belgijka - konwertytka islamska. Zginęła 9 listopada 2005 r. na południu od Bagdadu w samobójczym ataku, detonując ładunek wybuchowy, kiedy obok niej przejeżdżał amerykański konwój wojskowy ${ }^{29}$.

Analizując te $\mathrm{i}$ inne wydarzenia związane $\mathrm{z}$ aktywnością terrorystyczną na terenie Belgii w pierwszej dekadzie XXI w., patrząc na nie w kontekście kolejnych jakże tragicznych zamachów w USA i Europie, wydaje się, że problem ten w Belgii był ignorowany, bądź też delikatniej mówiąc - minimalizowany. Było to niebezpieczne, gdyż duża, napływowa część obywateli tego kraju (podobnie jak obywateli Francji) miała olbrzymie problemy z asymilacją. Tworzone były getta, w których poszanowanie drugiego człowieka, poszanowanie jego wyznania, światopoglądu, koncepcja państwa demokratycznego, dążenie do pokoju to wartości odległe i nieistotne. Wielu z tych ludzi prowadziło walkę z niewiernymi dążąc do stworzenia nowego, lepszego świata. Edwin Bakker - holenderski analityk - stwierdził, że „w Brukseli istnieją obszary, na których Policja miała małą możliwość oddziaływania. Obszary wydzielone, których mieszkańcy nie czują się częścią państwa belgijskiego"30.

Nad powyższym problemem $w$ badaniach nad terroryzmem w Unii Europejskiej początku XXI w. pochyliła się także Aleksandra Zięba z Uniwersytetu Warszawskiego. W swoich rozważaniach jako istotną przyczynę radykalizacji islamskiej wyraźnie wskazała błędną politykę imigracyjną, która przejawiała się w segregacji kulturowej, wyznaniowej, a także - co jeszcze raz warto podkreślić - geograficznej danych mniejszości (najjaskrawszym tego przykładem jest dzielnica Molenbeek w Brukseli czy getta muzułmańskie w Paryżu). W takiej sytuacji ,poczucie przynależności członka ugrupowania islamskiego nawiązuje do szerszej idei: ojczyzny, globalnej społeczności muzułmańskiej (ummy), kwestii palestyńskiej, w konflikcie do kultury europejskiej/zachodniej. Ten konflikt

\footnotetext{
27 Trabelsi v. Belgium, ECHR 140/10, 139 (European Court of Human Rights 2014-09-04) ("The Court accordingly concludes that the applicant's extradition to the United States of America amounted to a violation of Article 3 of the Convention".

${ }^{28}$ J. Burke, How Belgium became a breeding ground for international terrorists, „,The Guardian”, 16.11.2015.

${ }^{29}$ C.S. Smith, Raised as Catholic in Belgium, She Died as Muslim Bomber , „New York Times”, 6.12.2005, http://www.nytimes.com/2005/12/06/world/europe/raised-as-catholic-in-belgium-she-died-as-a-muslimbomber.html, (12.01.2019).

${ }^{30}$ J. Burke, How Belgium became a breeding ground for international terrorists, „, The Guardian”, 16.11.2015.
} 
jest podstawą narracji, indoktrynacji i umacniania motywacji, powiązanej z czynnikami indywidualnymi, czyli podatnością osoby na fascynację przemocą" ${ }^{31}$.

Już po zamachu w Paryżu, w miarę dokonywania kolejnych ustaleń okazało się, że to właśnie $\mathrm{z}$ Belgii przyjechali terroryści $\mathrm{i}$ to tam prowadziły kolejne tropy, niezbędne w ustaleniach dotyczących samych sprawców, jak i osób z nimi współpracujących. Co ciekawe, jedyny z dziewięciu zamachowców, który przeżył ataki terrorystyczne, Salah Abdeslam, zajmujący się wcześniej kontaktami i transportem zamachowców ${ }^{32}$ ukrył się właśnie na terenie Belgii, a w ucieczce pomagało mu dwóch obywateli tego kraju. Także dwa samochody wykorzystane do przeprowadzenia ataku miały belgijskie tablice rejestracyjne. Wypożyczył je w dniu zamachu Belg mieszkający we Francji. Jak podała tamtejsza prokuratura, bezpośrednio po zamachach zatrzymano siedem osób. Pięć wypuszczono już następnego dnia, dwie zostały jednak oskarżone o przynależność do grupy terrorystycznej i powiązania z zamachami. Zestawiając kolejne informacje pochodzące od policji i służb specjalnych Francji i Belgii, okazało się, że głównym organizatorem zamachów w Paryżu był Abdelhamida Abaaouda Belg marokańskiego pochodzenia. Zginął on w jednej obław przeprowadzonych przez Francuzów w ramach działań na rzecz walki z terroryzmem. Za działalność terrorystyczną został zaocznie skazany w Belgii na 20 lat więzienia.

\section{ZAOSTRZENIE PRAWA NA RZECZ WALKI Z TERRORYZMEM}

Z każdą kolejną informacją na tematy dotyczące działań terrorystów rosły też, wyrażane przez polityków, media i zwykłych obywateli poszczególnych państw, obawy co do możliwości następnych ataków. Szybko przekładały się one na poziom radykalizacji społeczności europejskiej, co pokazywały jasno sondaże i badania opinii publicznej. Coraz głośniejsze i coraz powszechniej wyrażane były negatywne poglądy na temat imigrantów i uchodźców. Dotyczyło to przede wszystkim ludzi pochodzących z bliskiego Wschodu i Afryki, choć dla przedstawicieli nacjonalistycznych, europejskich ugrupowań politycznych obawy o losy ich kraju związane z napływem „obcych” wyrażano także wobec przemieszczających się wewnątrz Unii Europejskiej mieszkańców samej Unii. Przełożyło się to chociażby na decyzje Brytyjczyków wyrażane w referendum na temat Brexitu.

Inaczej spoglądano także na demokratyczne prawa wolnościowe człowieka. Wraz z każdym kolejnym zamachem rosła liczba tych, którzy byli w stanie zrezygnować z części przyznanych im przez demokratyczne państwa wolności na rzecz bezpieczeństwa. Francja natychmiast skorzystała $\mathrm{z}$ zapisów ustawy antyterrorystycznej, wdrażając narzędzia przyznane służbom. Jednocześnie pojawiły się głosy mówiące o potrzebie kolejnych zmian

\footnotetext{
31 A. Zięba, Terroryzm w Unii Europejskiej na początku XXI wieku: wnioski dla Polski [w:] K. Czornik, M. Lakomy (red.), Dylematy bezpieczeństwa polityki Polski, na początku XXI wieku, Katowice 2014, s. 246.

${ }^{32}$ Le procureur fédéral belge sur Salah Abdeslam: „Personnellement, je ne l'aurais pas reconnu”, RTL.be, 21.03.2016, http://www.rtl.be/info/belgique/faits-divers/le-procureur-federal-belge-sur-salah-abdeslam-personn ellement-je-ne-l-aurais-pas-reconnu--803910.aspx, (14.01.2019).
} 
w kierunku zaostrzenia i tak dosyć radykalnych uregulowań. Starający się o nominację prezydencką Nicolas Sarkozy w trakcie jednej z debat zaproponował, by podejrzanych o związki z organizacjami terrorystycznymi aresztować bez procesu. Gdyby takie rozwiązanie weszło w życiem można było spodziewać się z tego tytułu kilku tysięcy aresztowań. Warto tu wspomnieć, że ówczesny premier Francji, Manuell Valls, ocenił liczbę sympatyków dżihadu $\mathrm{w}$ całym kraju na ponad 5 tysięcy. Proponowane rozwiązania prawne, nawet $\mathrm{w}$ tak zdeterminowanym do walki kraju jak Francja nie weszły w życie. Realizując zadania militarne, wprowadzając a następnie przedłużając stan wyjątkowy Francja ${ }^{33}$ postanowiła bronić republiki i jej wartości. Nie wycofano się z obietnicy przyjęcia prawie 30 tysięcy syryjskich uchodźców. Ogłaszający to, zaraz po paryskich zamachach, Holland od słuchającej jego słów publiczności otrzymał gromkie brawa ${ }^{34}$.

Analizując prawodawstwo francuskie należy wyraźnie podkreślić, że jest to kraj, w którym już od lat 90. XX w., po fali zamachów dokonanych przez algierskich fundamentalistów obowiązuje jedno z najbardziej restrykcyjnych uregulowań antyterrorystycznych. Zaostrzano je kilkakrotnie wraz z kolejnymi dokonanymi bądź udaremnionymi zamachami. I tak w 2005 r. parlament zaaprobował rozwiązania wzorowane na prawodawstwie brytyjskim (nowe prawo wprowadzono po zamachach w Londynie w lipcu 2005 r.), zwiększając kompetencje policji w zakresie ścigania i zapobiegnia aktom terroryzmu. Jak twierdził pełniący wówczas funkcję ministra spraw wewnętrznych Nicolas Sarkozy, ustawa ta „wyposażyła policją w bardziej efektywny arsenał środków, dając aparatowi bezpieczeństwa większą władzę w celu uniknięcia katastrofy" 35 . Nowe uregulowania, wprowadzone przy sprzeciwie partii opozycyjnych i organizacji broniących wolności obywatelskich, pozwoliły m.in. na rozwinięcie systemów monitorowania miejsc publicznych, takich jak lotniska, dworce kolejowe czy stacje metra, zwiększenie dopuszczalnego czasu przesłuchania podejrzanych o terroryzm, a także umożliwiły kontrolę zawartości skrzynek mailowych i historii połączeń telefonicznych. Zwolennicy takich rozwiązań w swojej narracji wykorzystali argument, iż to właśnie użycie kamer monitoringu pozwoliło zidentyfikować osoby odpowiedzialne za zamach bombowy w Londynie 7 lipca 2005 r., a zaostrzenie środków kontroli pomogło brytyjskim służbom policyjnym udaremnić próby kolejnych zamachów.

W 2015 r. niższa izba francuskiego parlamentu uchwaliła kolejną ustawę, która znacznie ułatwiała służbom wywiadowczym stosowanie podsłuchu i innych form inwigilacji w celu zapobiegania atakom terrorystycznym. Znosiła ona wymóg uzyskania zgody sądu na kontrolowanie rozmów telefonicznych, instalowanie kamuflowanych środków techniki operacyjnej, takich jak kamery, mikrofony czy też instalowanie szpiegującego oprogramowania w komputerach.

\footnotetext{
${ }^{33}$ Zgromadzenie Narodowe Francji z 13/14. 12.2016 r. na wniosek rządu zaaprobowało przedłużenie stanu wyjątkowego do 15.07.2017 r. Szef francuskiego MSW, Bruno Le Roux, uzasadnił wniosek ciągle istniejącym zagrożeniem terrorystycznym, Vide: depesza PAP, 14.12.2016.

${ }^{34}$ H. Orzechowski, Francja krwawi, ale się nie poddaje, op.cit.

35 P. Mechliński, Francja/ Przyjęcie ustawy antyterrorystycznej, 23.12.2005, Portal Spraw Zagranicznych, http://www.psz.pl/91-europa/francja-przyjecie-ustawy-antyterrorystycznej, (12.10.2018).
} 
Przewidywała także możliwość monitorowania metadanych telekomunikacyjnych. Wszystkie te środki miałyby być wdrażane wobec podejrzanych o bezpośrednie związki z terroryzmem w sytuacjach, kiedy służby muszą ścigać się z czasem. Wówczas decyzję o ich zastosowaniu podejmuje prokurator, musi być ona jednak w ciągu doby zatwierdzona przez sąd. Jeżeli do tego nie dojdzie, zebrane materiały nie mogą być wykorzystane. Sprzeciw opozycji i organizacji wolnościowych, obawiających się inwigilacji na niespotykaną dotąd skalę, na niewiele się zdał. Za przyjęciem ustawy głosowało 438 deputowanych, przeciw było 86 , a 42 wstrzymało się od głosu. Jak podkreślał premier Manuel Valls, ustawa ta miała mieć kluczowe znaczenie dla walki $\mathrm{z}$ terroryzmem, przestępczością zorganizowaną i szpiegostwem gospodarczym ${ }^{36}$.

$\mathrm{Na}$ mocy ustawy o wywiadzie z lipca 2015 r. Francja powołała do życia Narodową Komisję Kontroli Technik Wywiadowczych, będącą niezależnym organem opiniującym stosowanie technik wywiadowczych przez służby. W ramach prowadzonego przez nią nadzoru nad zarządzanymi inwigilacjami może wydawać zalecenia, a nawet wystąpić z odwołaniem od zastosowania techniki operacyjnej do Rady Stanu ${ }^{37}$.

Francuskie Zgromadzenie Narodowe przyjęło także ustawę o stanie wyjątkowym, w której kolejny już raz doszło do zaostrzenia uprawnień służb państwowych ograniczając jednocześnie część swobód obywatelskich. Ustawa ta dała ministrowi spraw wewnętrznych prawo do blokowania dowolnej strony internetowej promującej terroryzm lub nawołującej do niego. Przez grupy obywatelskie nowe prawo określono mianem ,cenzury Internetu” ${ }^{38}$.

Oczekiwania prawicowej i skrajnie prawicowej opozycji francuskiej co do zmian prawa W walce z terroryzmem poszły znacznie dalej pod koniec lipca 2015 r., tuż po zamachu w Nicei i po ataku dżihadystów na kościół w Normandii, kiedy to zabito 86-letniego księdza odprawiającego mszę. Nicolas Sarkozy - tym razem jako lider opozycyjnych Republikanów optował za prewencyjnym zatrzymywaniem bądź to $\mathrm{w}$ specjalnych ośrodkach, bądź w aresztach domowych wszystkich osób, które służby uznawały za ,zradykalizowane”, nawet jeśli nie popełniły jakiegokolwiek przestępstwa. Tylko według wstępnych szacunków mogło to dotyczyć aż 12 tysięcy osób. Oprócz tego zaproponował prewencyjne zamykanie tych wszystkich, którzy odbyli wyroki za działalność terrorystyczną. Opowiedział się także za bardziej stanowczym zamykaniem meczetów działających na terenie Francji, w których dominuje radykalny islam, oraz wydalaniem imamów go głoszących. Kara więzienia byłaby automatyczną sankcją dla tych Muzułmanów, którzy wrócili do Francji z krajów, gdzie walczyli w szeregach dżihadystów. Karane miało być także korzystanie ze stron internetowych dżihadystów ${ }^{39}$. Propozycje te zostały jednak zdecydowanie odrzucone przez prezydenta Hollande'a, który uznał obowiązujące dotychczas uregulowania za skuteczne

\footnotetext{
36 Francuzi będa mogli tatwiej inwigilować, tvn24.pl, 05.05.2015, http://www.tvn24.pl/wiadomosci-zeswiata,2/francja-nowa-ustawa-o-inwigilacji,539658.html, (20.11.2018).

${ }^{37}$ W. Adamska, Zwalczanie terroryzmu..., op. cit.

${ }^{38}$ Ibidem.

39 Francja: Hollande odrzuca apele o zaostrzenie prawa antyterrorystycznego, rp.pl, 26.07.2016, http://www.rp.pl/Terroryzm/160729377-Francja-Hollande-odrzuca-apele-o-zaostrzenie-prawa-

antyterrorystycznego.html\#ap-1, (28.10.2018).
} 
i wystarczające. Siłą Francji w walce miały być idee konstytucyjne, a nie ich podważanie. „Ograniczenie naszych swobód, uchylenie naszych zasad konstytucyjnych nie zwiększyłoby skuteczności naszej walki z terroryzmem i osłabiłoby spójność tak potrzebną naszemu narodowi” - stwierdził Hollande w orędziu telewizyjnym, dodając: „Ta wojna będzie długa. Nasza demokracja znalazła się na celowniku. Jest celem, a będzie naszą tarczą. Francuzki i Francuzi, stwórzmy blok. W ten sposób wygramy wojnę z nienawiścią i fanatyzmem. Zapewniam, że ją wygramy" 40 .

\section{POLSKIE ROZWIĄZANIA PRAWNE NA RZECZ ZWIĘKSZENIA EFEKTYWNOŚCI DZIAŁAŃ ANTYTERRORYSTYCZNYCH}

Wydarzenia o charakterze terrorystycznym w Europie zachodniej dały pretekst do uchwalenia w bardzo krótkim czasie ustawy o działaniach antyterrorystycznych ${ }^{41} \mathrm{w}$ Polsce. Jak deklarowano chociażby w komunikacie Kancelarii Prezydenta RP, miała ona ,podnieść efektywność działania polskiego systemu antyterrorystycznego, zwiększyć bezpieczeństwo obywateli i doprowadzić do lepszej koordynacji działań służb"42. Ustawa wyraźnie wskazuje podmiot odpowiedzialny za zapobieganie zdarzeniom o charakterze terrorystycznym, którym jest szef Agencji Bezpieczeństwa Wewnętrznego. Jednakże do działań związanych z przygotowaniem do przejmowania kontroli nad zdarzeniami o charakterze terrorystycznym w drodze zaplanowanych przedsięwzięć, reagowaniem w przypadku wystąpienia takich zdarzeń oraz odtwarzaniem zasobów przeznaczonych do reagowania na te zdarzenia wyznaczono ministra spraw wewnętrznych.

Zapisany w ustawie podział kompetencyjny w obszarze szeroko ujętej problematyki antyterrorystycznej został uznany przez niektórych - jak chociażby przez Piotra Chorbota - za najważniejszy ${ }^{43}$. Tym samy można wnioskować, że wcześniejsze rozwiązania nie były skuteczne i wprowadzały chaos decyzyjny w zakresie uprawnień do działań i podejmowania decyzji w sytuacji kryzysowej.

Szef ABW, oprócz zadań związanych z koordynacją czynności analityczno-informacyjnych podejmowanych przez służby specjalne oraz wymianą informacji przekazywanych przez Policję, Staż Graniczną, Biuro Ochrony Rządu, Państwową Straż Pożarną, Służbę Celną, Generalnego Inspektora Informacji Finansowej, Generalnego Inspektora Kontroli Skarbowej, Żandarmerię Wojskową i Rządowe Centrum Bezpieczeństwa zyskał uprawnienie do prowadzenia rejestru osób, które mogą być związane z aktywnością terrorystyczną. Osoby te w ustawie podzielono na cztery grupy:

\footnotetext{
${ }^{40}$ Ibidem.

${ }^{41}$ Ustawa z 10.06.2016 r. o działaniach antyterrorystycznych, Dz.U. 2016 poz.904.

42 Prezydent RP podpisal m.in. ustawe terrorystyczna, 22.06.2016, prezydent.pl, http://www.prezydent.pl/ aktualnosci/wydarzenia/art,264,dziewiec-ustaw-z-podpisem-prezydenta-rp.html, (21.11.2018).

${ }^{43}$ Piotr Chorbot, Ustawa o działaniach antyterrorystycznych. Komentarz do niektórych regulacji [w:] Piotr Borczaniuk (red.), Uprawnienia stużb specjalnych z perspektywy współczesnych zagrożén bezpieczeństwa narodowego, Warszawa 2017, s. 68.
} 
1. osoby podejmujące działalność na rzecz organizacji terrorystycznych lub organizacji związanych z działalnością terrorystyczną lub członkowie tych organizacji;

2. osoby poszukiwane prowadzące działalność terrorystyczną bądź osoby podejrzewane o popełnienie przestępstw o charakterze terrorystycznym, wobec których w Rzeczypospolitej Polskiej zostało wydane zarządzenie o zatrzymaniu, poszukiwaniu lub postanowienie o poszukiwaniu listem gończym czy europejskim nakazem aresztowania;

3. osoby, wobec których istnieje uzasadnione podejrzenie, że mogą prowadzić działania zmierzające do popełnienia przestępstw o charakterze terrorystycznym;

4. osoby uczestniczące $\mathrm{w}$ szkoleniach terrorystycznych lub podróżujące $\mathrm{w}$ celach popełnienia przestępstwa o charakterze terrorystycznym ${ }^{44}$.

Dodatkowo tzw. ustawa antyterrorystyczna wymienia cały wachlarz środków, jakimi dysponować mogą służby odpowiedzialne za bezpieczeństwo. Co ciekawe, w ustawie wyraźnie wskazano środki, które mogą być stosowane wobec osób nie będących obywatelami polskimi - wskazując poniekąd przewidywane przez twórców ustawy źródło zagrożenia terrorystycznego. I tak $\mathrm{w}$ celu rozpoznawania, zapobiegania i zwalczania przestępstw o charakterze terrorystycznym szef ABW może, wobec osób nie będących obywatelami RP, na okres do trzech miesięcy, zarządzić niejawne prowadzenie czynności operacyjnorozpoznawczych. Może chociażby uzyskiwać i utrwalać treści rozmów, obrazów, dźwięków czy korespondencji internetowej, a także kontrolować zawartość przesyłek.

Dążąc do usprawnienia przeciwdziałania finansowaniu terroryzmu w ustawie uregulowano problem dostępu do informacji stanowiących tajemnicę bankową. Szef ABW zyskał dostęp do przetwarzanych przez banki informacji stanowiących tajemnicę bankową. Sporo kontrowersji wzbudziła także możliwość blokowania przez państwo dostępności do określonych usług, bądź danych teleinformatycznych w sieci internetowej w ramach walki z terroryzmem. Dokonać tego może Sąd Okręgowy na wniosek szefa ABW i po uzyskaniu zgody prokuratora generalnego.

Zmianą, która bezpośrednio dotknęła miliony Polaków, był obowiązek rejestracji kart pre-paid do 1 lutego 2017 r. Do tej pory sprzedawane i użytkowane anonimowo, na mocy zmienionego prawa telekomunikacyjnego ${ }^{45}$ objęte zostały obowiązkiem przypisania i zarejestrowania danych nabywców. Co ciekawe, ta zmiana prawna w istotny sposób przyczyniła się do znaczącego spadku liczby użytkowanych kart przedpłaconych w Polsce. Według danych GUS z ponad 25 do 18,4 mln sztuk ${ }^{46}$.

Ustawa antyterrorystyczna wprowadziła także - postulowaną od lat przez przedstawicieli służb odpowiedzialnych za bezpieczeństwo - możliwość oddania tzw. strzału ratunkowego, czyli oddania strzału przez snajpera do osoby dokonującej zamachu terrorystycznego.

\footnotetext{
${ }^{44}$ Art. 6.1., Ustawa z 10.06.2016 r. o działaniach antyterrorystycznych, Dz.U. 2016 poz.904.

45 Art. 43, Dz.U. z 2014 r. poz. 243, ze. zm.

${ }^{46}$ S. Czubkowska, Telekomom pomogła ustawa antyterrorystyczna. Z rynku zniknęło 8 mln przedpłaconych kart, https://serwisy.gazetaprawna.pl/telekomunikacja/artykuly/1061558,karty-prepaid-8-mln-ustawa-antyterro rystyczna.html, (09.01.2019).
} 
Opisywane powyżej zmiany prawa wywołały spore zaniepokojenie podmiotów zaangażowanych w dbałość o przestrzeganie praw człowieka w Polsce. Już na etapie projektowania swoje wątpliwości zgłaszał Rzecznik Praw Obywatelskich - Adam Bodnar. Kiedy ustawa została uchwalona złożył do Trybunału Konstytucyjnego wniosek o zbadanie konstytucyjności części przyjętych rozwiązań. Rzecznik wyraźnie zaznaczył, że cel przyświecający twórcom ustawy jest słuszny, zadając jednocześnie pytanie: jak chronić bezpieczeństwo nie grożąc wolności? „Chodzi bowiem nie tylko o to, by państwo zapewniło bezpieczeństwo, lecz by hasłem walki z terroryzmem nie ingerowało $\mathrm{w}$ prawa $\mathrm{i}$ wolności człowieka w sposób nieproporcjonalny i nadmierny. Wtedy bowiem środki ochrony bezpieczeństwa publicznego w postaci legalnie dopuszczalnej działalności organów ścigania oraz służb specjalnych same w sobie stwarzają zagrożenie dla tych wolności” pisał A. Bodnar ${ }^{47}$. Rzecznik kwestionował m.in. samą definicję pojęcia „zdarzenia o charakterze terrorystycznym" jako mało precyzyjną, dającą pole do zbyt szerokiej interpretacji, zbyt szeroki dostęp szefa ABW do danych zgromadzonych w rejestrach publicznych i ewidencjach, czy prowadzenie przez ABW kolejnego wykazu osób podejrzanych. Ponadto krytyce RPO poddane zostały: możliwość blokowania danych informatycznych, obowiązek rejestracji kart przedpłaconych, dopuszczalność pobierania i przetwarzania danych biometrycznych cudzoziemców, możliwość natychmiastowego wydalenia cudzoziemca podejrzewanego o działalność terrorystyczną, oddanie strzału ratunkowego czy w końcu możliwość zastosowania tymczasowego aresztowania na podstawie uprawdopodobnienia popełnienia, usiłowania lub przygotowania do popełnienia przestępstwa o charakterze terrorystycznym ${ }^{48}$.

Swoje uwagi do nowego prawa antyterrorystycznego zgłaszała także Generalny Inspektor Ochrony Danych Osobowych (GIODO) - Edyta Bielak-Jomaa. W piśmie z 30 maja 2016 r. wskazała na brak unormowań określających zasady weryfikacji przez ABW przydatności gromadzonych i przetwarzanych danych. Za wysoce kontrowersyjne i naruszające hierarchiczność źródeł prawa uznała rozwiązanie, w myśl którego niemal wszystkie regulacje dotyczące prowadzenia wykazu osób mogących mieć związek $\mathrm{z}$ przestępstwami o charakterze terrorystycznym znalazłyby się $\mathrm{w}$ niejawnym zarządzeniu szefa ABW. GIODO zwraca też uwagę na: rozszerzenie katalogu podmiotów uprawnionych do stosowania obserwacji obywateli, „co wpływa na prawo do prywatności osób obserwowanych", brak regulacji zasad informowania osób o objęciu monitoringiem oraz dostęp do nagrań, zbyt szerokie kryterium pozwalające na blokowanie treści w Internecie.

Odnosząc się do obowiązku identyfikacji użytkowników kart przedpłaconych Edyta Bielak-Jomaa zaznaczyła, że osiągniecie tego celu niekoniecznie musi wiązać się z obowiązkiem prawnym rejestracji numeru. Po pierwsze, ustalenie danych użytkownika jest pośrednio możliwe przez weryfikację numeru IMEI, a po drugie, brak takiego obowiązku

\footnotetext{
${ }^{47}$ The Commissioner for Human Rights challenges the Anti-Terrorism Act before the Constitutional Tribunal, https://www.rpo.gov.pl/pl/content/RPO-skarzy-ustawe-antyterrorystyczna-do-TK, (28.11.2018).

48 Projekt ustawy o działaniach antyterrorystycznych. Opinia RPO, https://www.rpo.gov.pl/pl/content/projektustawy-o-dzialaniach-antyterrorystycznych-opinia-rpo, (07.12.2018).
} 
w innych krajach może skutkować wykorzystaniem przez osoby pragnące uniknąć identyfikacji karty SIM zakupionych u zagranicznych operatorów ${ }^{49}$.

Warto dodać, że swoje uwagi zgłaszały także organizacje pozarządowe zajmujące się tematyką ochrony praw i wolności człowieka. Fundacja ePaństwo uznała proponowane przepisy za pozorną troskę o bezpieczeństwo, widząc w nich, „pozorne rozstrzygnięcia naruszające prawa człowieka" ${ }^{" 50}$. Ustawę bardzo ostro skrytykowała fundacja Panoptykon, twierdząc, że jest to „kolejne zwiększenie - i tak już szerokich - uprawnień służb specjalnych i organów ścigania kosztem praw każdego z nas" ${ }^{\text {51. }}$

\section{KRYZYS IMIGRACYJNY JAKO DETERMINANTA ZMIAN PRAWA ANTYTERRORYSTYCZNEGO}

Skuteczną walkę z terroryzmem z pewnością bardzo skomplikował mający miejsce w latach 2014-2016 kryzys imigracyjny i masowy napływ do Europy milionów uchodźców, wśród których mogły ukrywać się osoby negatywnie ustosunkowane do cywilizacji zachodniej. Z danych na temat imigrantów i uchodźców opublikowanych w „Biuletynie Migracyjnym” Ośrodka Badań nad Migracjami Uniwersytetu Warszawskiego wynika, że na przestrzeni dwóch lat 2014 i 2015 r. nastąpił bardzo znaczny wzrost liczby przybyszy do Europy. Jak podaje Wysoki Komisarz Narodów Zjednoczonych ds. Uchodźców, od stycznia do końca listopada 2015 r. 894511 osób przedostało się do Europy przez Morze Śródziemne. Jest to aż czterokrotnie więcej niż w całym 2014 r. Podobna tendencja zarysowała się w danych zbieranych przez Frontex (Europejska Agencja Zarządzania Współpracą Operacyjną na Zewnętrznych Granicach Państw Członkowskich Unii Europejskiej). O ile w całym 2014 r. odnotowano 282 tysiące przypadków nielegalnego przekroczenia granicy zewnętrznej UE, o tyle w ciągu pierwszych 10 miesięcy 2015 r. było ich aż $1236887^{52}$.

Problem bezpieczeństwa granic UE, zwalczanie terroryzmu, radykalizacja poglądów wyrażanych w Internecie, wykorzystanie globalnej sieci do działań propagandowych Państwa Islamskiego, wymiana informacji na temat bojowników islamskich docierających do UE to tematy, nad którymi w styczniu 2016 r. na nieformalnym posiedzeniu Rady ds. Sprawiedliwości i Spraw Wewnętrznych w Amsterdamie dyskutowali ministrowie spraw wewnętrznych UE. W trakcie tego spotkania omówiono opublikowany przez Komisję Europejską pakiet graniczny. Dokument ten zakładał powołanie Europejskiej Straży Granicznej i Przybrzeżnej odpowiedzialnej za zintegrowane zarządzanie bezpieczeństwem

\footnotetext{
49 Pismo GIODO z dnia 30.05.2016 do Adama Podgórskiego - Zastępcy Szefa Kancelarii Sejmu RP, http://orka.sejm.gov.pl/Druki8ka.nsf/0/A086D7A2F73000EBC1257FC50039BC7C/\%24File/516-002.pdf, (08.12.2018).

50 Pismo fundacji ePaństwo z 02.06.2016 do Marszałka Sejmu, http://orka.sejm.gov.pl/Druki8ka.nsf/ 0/2EDD11CF760F8FF4C1257FCC0044D6DD/\%24File/516-003.pdf, (25.11.2018).

${ }^{51} \mathrm{~W}$. Klicki, Ustawa antyterrorystyczna wchodzi $w \dot{z y c i e}$ - co się zmienia, https://panoptykon.org/wiadomosc/ ustawa-antyterrorystyczna-wchodzi-w-zycie-co-sie-zmienia, (08.01.2019).

52 Biuletyn Migracyjny, nr 53, grudzień 2015, s.4.
} 
granic zewnętrznych UE. Kontrowersje wzbudził jednak zapis umożliwiający podjęcie interwencji przez nowo powoływaną straż w przypadku braku zgody państwa, na którego terenie byłaby potrzeba podjęcia interwencji. Polski minister spraw wewnętrznych i administracji, Mariusz Błaszczak, domagał się zmiany polityki azylowej państw zachodniej Europy, tak by ,zlikwidować czynniki przyciągające fale imigrantów do Europy”53.

Europa ukształtowana $\mathrm{w}$ duchu humanizmu i poszanowania praw człowieka w oficjalnych wystąpieniach unijnych urzędników i większości przywódców państw europejskich deklarowała niesienie pomocy uciekającym przed terrorem ze strony dżihadystów. Podkreślano to wielokrotnie. Unikano jednocześnie identyfikacji terrorystów i otoczenia im sprzyjającego z jakąkolwiek nacją czy wyznaniem. Zapewniano wręcz, że nie jest to wojna przeciwko jakiejkolwiek cywilizacji, bo zamachowcy po prostu cywilizacji nie reprezentują. Nie zawsze szło to w parze z nastrojami społecznymi, które z każdym kolejnym zamachem radykalizowały się coraz bardziej, wskazując jako odpowiedzialne za nie konkretne grupy narodowościowo-wyznaniowe. I wbrew niektórym przekazom wcale nie dotyczyło to tylko Polski, choć i tu nastroje wobec imigrantów uległy pogorszeniu. Przykładowo, w Szwajcarii z inicjatywy prawicowej Szwajcarskiej Partii Ludowej 28 lutego 2016 r. przeprowadzono referendum dotyczące automatycznego wydalania cudzoziemców popełniających przestępstwo na terenie tego kraju, przy czym osoba poddana takiej procedurze nie miałaby prawa odwołania się do sądu. Taka deportacja obejmowałaby wszystkich, którzy dopuścili się nie tylko czynów będących przestępstwami ciężkimi, lecz także tych o mniejszym ciężarze gatunkowym w okresie ostatnich 10 lat, czyli np. przekroczeń prędkości. Według wstępnych szacunków restrykcje te mogłyby obejmować nawet 10 tysięcy osób. Zwolennicy tych rozwiązań w referendum ponieśli klęskę. 59\% uprawnionych do głosowania opowiedziało się przeciwko takim rozwiązaniom i tym samym Szwajcara - mimo nasilających się postaw antyimigranckich - nie stała się najbardziej restrykcyjnym w Europie państwem w zakresie przepisów dotyczących cudzoziemców. Wcześniej od 2010 r. w Szwajcarii obowiązywała deportacja z kraju cudzoziemców skazanych za najcięższe przestępstwa (zabójstwa, gwałty, rozboje) oraz wyłudzających zasiłki z pomocy społecznej. Odbywało się to jednak dopiero po odbyciu kary, z możliwością wydania sądowego orzeczenia o niewydalaniu i nie miało automatycznego charakteru ${ }^{54}$.

W odczuciu społecznym zagrożenie terrorystyczne w Europie i Stanach Zjednoczonych nadal kształtuje się na bardzo wysokim poziomie. Z danych opublikowanych w listopadzie 2016 r. z przeprowadzonego dla „Le Figaro” wyników badania realizowanego w ramach „Barometru Zagrożenia Terrorystycznego” wynika, że najbardziej zagrożeni czują się mieszkańcy Francji - kraju dotkniętego ostatnimi zamachami. Aż 96\% badanych oceniło je jako wysokie, z czego 45\% stwierdziło, że jest ono „bardzo wysokie”. Dla porównania

\footnotetext{
53 Komunikat MSWiA, https://www.mswia.gov.pl/pl/aktualnosci/14110,Minister-Mariusz-Blaszczak-nanieformalnym -posiedzeniu-Rady-JHA-w-Amsterdamie.html, (15.01.2019).

${ }^{54}$ Biuletyn Imigracyjny, nr 54, czerwiec 2016, s.8.
} 
w Wielkiej Brytanii i Stanach Zjednoczonych 84\% mieszkańców uznało stan zagrożenia za „wysoki”, choć trendy w ocenach społecznych w tych krajach były różne. W USA odsetek osób, dla których zagrożenie jest wysokie, w przeciągu zaledwie 3 miesięcy wzrósł o 9\% (co mogło być efektem podjęcia tematów zagrożenia terroryzmem i nielegalnej imigracji w trakcie trwającej dosyć ostrej kampanii prezydenckiej), na Wyspach Brytyjskich zaś spadł o dwa punkty procentowe. W Niemczech $80 \%$ obywateli uznało zagrożenie za wysokie i był to wynik o 6 punktów procentowych niższy aniżeli w badaniach z kwietnia tego samego roku. Mniej zaniepokojeni groźbą terroryzmu wydają się Włosi. Tu 69\% badanych oceniło zagrożenie dla ich kraju jako wysokie. Stanowiło to dosyć gwałtowny spadek wobec badań z lipca 2015 r., kiedy to podobnego zdania było aż $84 \%$ respondentów ${ }^{55}$.

\section{Podsumowanie}

Zagrożenie terrorystyczne występujące $\mathrm{z}$ różnym natężeniem i w różnej postaci jest cały czas realne. To, co wydawało się niewyobrażalne, po kolejnych zamachach - najpierw na WTC w Nowym Jorku, a później w Londynie czy Madrycie - zmieniło percepcję wszystkich: począwszy od rządzących poprzez służby odpowiedzialne za bezpieczeństwo, organizacje międzynarodowych zaangażowane $\mathrm{w}$ walkę $\mathrm{z}$ terroryzmem, po zwykłych ludzi w zakresie potrzebny wyposażenia państwa i jego służb w skuteczne narzędzia i uprawnienia.

Jak pokazują przykłady poszczególnych państw, zastosowane rozwiązania były różne, przy czym praktycznie każde wiązało się z ograniczeniem ludzkich wolności w imię dbałości o bezpieczeństwo. Granice obu tych wartości, jak widać, nie są stałe i ulegają ciągłym zmianom. Nikogo już dziś nie dziwi zdejmowanie paska czy butów w trakcie kontroli bezpieczeństwa na lotnisku ani przechodzenie przez odpowiedni skaner wykrywający metal czy substancje niebezpieczne. O wiele większe jest też przyzwolenie na stosowanie w szerszym zakresie metod i form pracy operacyjnej, na zbieranie danych osobowych po to, by uchronić społeczeństwo przed terroryzmem. Obawy i protesty pojawiają się jednak wszędzie tam, gdzie niedookreślone są zasady nadzoru nad wykorzystaniem tych narzędzi przez służby bądź też zbyt szerokim ich zastosowaniem.

\section{BIBLIOGRAFIA}

Adamska Weronika. 15.11.2015. „Zwalczanie terroryzmu we Francji: między faktami a mitami” W https://panoptykon.org/wiadomosc/zwalczanie-terroryzmu-we-francjimiedzy-faktami-mitami.

AFP. 07.01.2015. Raport agencji AFP: “Attaque de Charlie Hebdo”. In https://www.afp.com/ fr/attaque-de-charlie-hebdo.

\footnotetext{
55 Raport z badań IFOP Baromètre De L'évaluation De La Menace Terroriste - Vague 32 (Focus International), 14.11.2016, http://www.ifop.com/?option=com_publication\&type=poll\&id=3553, (24.11.2018).
} 
Austria: Rośnie liczba osób powiązanych z walczącymi islamistami. 22.08.2014. W http://wpolityce.pl/swiat/210482-austria-rosnie-liczba-osob-powiazanych-zwalczacymi-islamistami;

BBC. 15.12.2015. Paris attacks: French police arrest suspect In http://www.bbc.co.uk/ news/world-europe-35102595;

Biuletyn Imigracyjny nr 54. czerwiec 2016.

Biuletyn Migracyjny nr 53. grudzień 2015.

Borczaniuk Piotr (red.). 2017. Uprawnienia służb specjalnych z perspektywy współczesnych zagrożeń bezpieczeństwa narodowego. Warszawa; Emów: Agencja Bezpieczeństwa Wewnętrznego. Centralny Ośrodek Szkolenia im. gen. dyw. Stefana Roweckiego "Grota".

Burke Jason. 16.11.2015. "How Belgium became a breeding ground for international terrorists". The Guardian.

Cécile Ducourtieux, Patrick Roger. 17.11.2015. Déficits : Bruxelles comprend la „priorité” donnée par la France ,à la sécurité”. Le Monde In http://www.lemonde.fr/attaques-aparis/article/2015/11/17/francois-hollande-se-delivre-du-pacte-destabilite_4811769_4809495.html.

Chorbot Piotr. 2017. Ustawa o działaniach antyterrorystycznych. Komentarz do niektórych regulacji W Piotr Borczaniuk (red.) Uprawnienia służb specjalnych z perspektywy współczesnych zagrożeń bezpieczeństwa narodowego. Warszawa.

Czubkowska Sylwia 18.11.2019. Telekomom pomogła ustawa antyterrorystyczna. Z rynku zniknęło $8 \mathrm{mln}$ przedpłaconych kart. W https://serwisy.gazetaprawna.pl/telekomuni kacja/artykuly/1061558,karty-prepaid-8-mln-ustawa-antyterrorystyczna.html.

Daily Mail. 14.11.2015. David Cameron warns there may be British casualties in the Paris terror attack and tells France: „We will do whatever we can to help" In http://www.dailymail.co.uk/news/article-3318273/We-help-David-Cameron-chairemergency-Cobra-meeting-Paris-attacks-British-nationals-France-warned-stayindoors.html\#ixzz4QMaWf8x8.

Daily Mail. 14.11.2015. http://www.dailymail.co.uk/news/article-3318086/11-dead-terroristsopen-fire-Paris-restaurant.html.

Daily Mail. 17.11.2015. Joyous crowd wave and smile as they enjoy Eagles Of Death Metal concert... before 89 of them were murdered by ISIS gunmen In http://www.dailymail.co.uk/news/article-3320420/Joyous-crowd-wave-smile-enjoyEagles-Death-Metal-concert-just-moments-89-murdered-ISIS-gunmen.html.

Daily Mirror. 16.11.2015.

Dekret nr 2015-125 z dnia 05 lutego 2015 odnoszący się do blokowania witryn skutkujących aktami terroryzmu lub które propagują pornografię nieletnich. legifrance.gouv.fr. https://www.legifrance.gouv.fr/affichTexte.do?cidTexte=JORFTEXT000030195477.

Die Welt. 16.11.2015. Das sind die offenen Fragen nach dem Terror von Paris In https://www.welt.de/politik/ausland/article148867136/Das-sind-die-offenen-Fragennach-dem-Terror-von-Paris.html.

Frignani Rinaldo. 16.11.2019. Giubileo, arrivano i rinforzi Entro breve altri 1.500 militari. roma.coriere.it. In http://roma.corriere.it/notizie/cronaca/15_dicembre_21/giubileoarrivano-rinforzi-entro-breve-altri-1500-militari-09994f46-a7fc-11e5-927a-

42330030613b.shtml?refresh_ce-cp. 
Henn Peter. 17.11.2015. Francois Hollande declares France is now at WAR with ISIS with second night of bombings. Express In http://www.express.co.uk/news/world/619784/ Hollande-France-war-ISIS-Paris-attacks.

Jason Burke. 16.11.2015. "How Belgium became a breeding ground for international terrorists". The Guardian.

Komunikat MSWiA. 25.11.2020. W https://www.mswia.gov.pl/pl/aktualnosci/14110, Minister-Mariusz-Blaszczak-na-nieformalnym-posiedzeniu-Rady-JHA-wAmsterdamie.html.

Le Monde. 13.11.2015. http://www.lemonde.fr/attaques-a-paris/video/2015/11/16/hollandemaintient-sa-position-la-france-est-en-guerre_4811152_4809495.html.

Le Monde.fr. 2015. Attaques à Paris : le point sur l'enquête et le déroulé des attaques. In http://www.lemonde.fr/societe/article/2015/11/13/fusillade-meurtriereparis_4809485_3224.html\#ZYBoBIuh7diAApS7.99.

Le Parisien. 15.05. 2015. http://www. leparisien.fr/faits-divers/jihadisme-cazeneuve-detaille1-origine-des-francais-impliques-19-05-2015 -4783609.php.

Mechliński Przemysław. 23.12.2005. Francja/ Przyjęcie ustawy antyterrorystycznej. Portal Spraw Zagranicznych W http://www.psz.pl/91-europa/francja-przyjecie-ustawy-antyterrorystycznej.

Mouillard Sylvain, Willy Le Devin, Ismael Halissat. 21.07.2016. Attentat de Nice: la réponse de «Libération» à Bernard Cazeneuve In http://www.liberation.fr/france/2016/07/21/ attentat-de-nice-la-reponse-de-liberation-a-bernard-cazeneuve_1467612.

Neumann P. 26.01.2015. Foreign fighter total in Syria/Iraq now exceeds 20,000; surpasses Afghanistan conflict in the 1980s In http://icsr.info/2015/01/foreign-fighter-totalsyriairaq-now-ex- ceeds-20000-surpasses-afghanistan-conflict-1980s/.

Orzechowski Hubert. 13.11.2016. Francja krwawi, ale się nie poddaje. Newsweek W http://www.newsweek.pl/swiat/rok-po-zamachach-w-paryzu-jak-francja-walczy-zisis, artykuly,400450,1.html.

PAP. 12.11.2015. Liban: Podwójny atak bombowy. Co najmniej 41 zabitych i 200 rannych. Depesza Polskiej Agencji Prasowej.

Pismo fundacji ePaństwo z 02.06.2016 do Marszałka Sejmu W http://orka.sejm.gov.pl/ Druki8ka.nsf/0/2EDD11CF760F8FF4C1257FCC0044D6DD/\%24File/516-003.pdf.

Pismo GIODO z dnia 30.05.2016 do Adama Podgórskiego - Zastępcy Szefa Kancelarii Sejmu RP W http://orka.sejm.gov.p1/Druki8ka.nsf/0/A086D7A2F73000EBC125 7FC50039BC7C/\%24File/516-002.pdf.

prezydent.pl. 22.06.2016. Prezydent RP podpisałm.in. ustawę terrorystyczną W http://www.prezydent.pl/aktualnosci/wydarzenia/art,264,dziewiec-ustaw-zpodpisem-prezydenta-rp.html.

Projekt ustawy o działaniach antyterrorystycznych. Opinia RPO W https://www.rpo.gov.pl/ $\mathrm{pl}$ /content/projekt-ustawy-o-dzialaniach-antyterrorystycznych-opinia-rpo.

Raport $\mathrm{z}$ badań IFOP baromètre de l'évaluation de la menace terroriste - vague 32 (focus international). 14.11.2016. http://www.ifop.com/?option=com_publication\&type=poll \&id $=3553$.

Reuters. 12.11.2015. European swoop seizes 15 Islamists police say planning attacks" In http://uk.reuters.com/article/uk-italy-arrests-idUKKCNOT10NZ20151112. 
rp.pl. 26.07.2016. Francja: Hollande odrzuca apele o zaostrzenie prawa antyterrorystycznego W http://www.rp.pl/Terroryzm/160729377-Francja-Hollande-odrzuca-apele-ozaostrzenie-prawa-antyterrorystycznego.html\#ap-1.

RTL.be. 21.03.2016. Le procureur fédéral belge sur Salah Abdeslam: "Personnellement, je ne l'aurais pas reconnu In http://www.rtl.be/info/belgique/faits-divers/le-procureur-federalbelge-sur-salah-abdeslam-personnellement-je-ne-1-aurais-pas-reconnu--803910.aspx.

Rubin Alissa J. 12.11.2016. Paris: One year on. The New York Times In http://www.nytimes.com/2016/11/13/world/europe/paris-one-year-on.html.

Servizio Informazione Religiosa. 15.07.2016. In http://agensir.it/quotidiano/2016/7/15/papafrancesco-condanna-per-follia-omicida-a-nizza/.

Smith Craig S. 6.12.2005. Raised as Catholic in Belgium, She Died as Muslim Bomber. New York Times In http://www.nytimes.com/2005/12/06/world/europe/raised-as-catholic-inbelgium-she-died-as-a-muslim-bomber.html.

The Commissioner for Human Rights challenges the Anti-Terrorism Act before the Constitutional Tribunal. 11.11.2019. In https://www.rpo.gov.pl/pl/content/RPOskarzy-ustawe-antyterrorystyczna-do-TK.

tvn24.pl. 05.05.2015. Francuzi będą mogli łatwiej inwigilować W http://www.tvn24.pl/ wiadomosci-ze-swiata,2/francja-nowa-ustawa-o-inwigilacji,539658.html.

Tvn24.pl. 24.04.10.2019. Katastrofa rosyjskiego samolotu W http://www.tvn24.pl/ raporty/katastrofa-rosyjskiego-samolotu, 1021.

Ustawa z 10.06.2016 roku o działaniach antyterrorystycznych, Dz.U. 2016 poz.904.

Ustawa z 16.07.2004 Prawo telekomunikacyjne, Dz. U. z 2014 r. poz. 243, 827, 1198, z 2015 r. poz. 1069, 1893, 2281, z 2016 r. poz. 147, 542, 903, 904.

Wojciech Klicki. 07.01.2020. Ustawa antyterrorystyczna wchodzi w życie - co się zmienia W https://panoptykon.org/wiadomosc/ustawa-antyterrorystyczna-wchodzi-w-zycie-cosie-zmienia.

Wróblewska-Łysik Małgorzata. 2015. „Zaangażowanie Francji w walkę z terroryzmem po zamachu na „Charlie”. Bezpieczeństwo Narodowe nr 3 : 67-90.

Wystąpienie telewizyjne prezydenta Francois Holland'a. 15.07.2016. W http://www.rfi.fr/ france/20160715-attaque-nice-francois-hollande-parle-acte-terroriste.

Zięba Aleksandra. 2014. Terroryzm w Unii Europejskiej na początku XXI wieku: wnioski dla Polski W K. Czornik, M. Lakomy (red.), Dylematy bezpieczeństwa polityki Polski, na początku XXI wieku, 241-261. Katowice. 